\title{
УПРАВЛІННЯ САМООСВІТНЬОЮ ДІЯЛЬНІСТЮ СТУДЕНТІВ ІНЖЕНЕРНИХ СПЕЦАЛЬНОСТЕЙ У ПРОЦЕСІ ВИВЧЕННЯ ВИЩОЇ МАТЕМАТИКИ ІЗ ЗАСТОСУВАННЯМ РІЗНОРІВНЕВИХ ЗАВДАНЬ
}

Квітка Т. В. Управління самоосвітньою діяльністю студентів інженерних спеціальностей у процесі вивчення вищої математики із застосуванням різнорівневих завдань.

У статті запропоновано варіант управління самоосвітньою діяльністю студентів під час вивчення окремих тем інтегрального числення із застосуванням різнорівневих завдань, що, на думку автора, дозволяє поступово інтегрувати студентів перших курсів до оволодіння уміннями та навичками самоосвітньої діяльності. Розглянуті функції управління самоосвітньою діяльністю студентів на прикладі вивчення теми «Невизначений інтеграл» для напрямів підготовки «Електротехніка та електротехнології» та «Електромеханіка».

Ключові слова: самоосвітня діяльність студентів, різнорівневі завдання, вища математика.

Квитка Т. В. Управление самообразовательной деятельностью студентов инженерных специальностей при изучении высшей математики с применением разноуровневых заданий.

В статье предложен вариант управления самообразовательной деятельностью студентов при изучении отдельных тем интегрального исчисления с применением разноуровневых заданий, что, по мнению автора, позволяет постепенно интегрировать студентов первых курсов в самообразовательную деятельность. Рассматриваются функции управления самообразовательной деятельностью студентов на примере изучения темы «Неопределённый интеграл» для направлений подготовки «Электротехника и электротехнологии» и «Электромеханика».

Ключевые слова: управление самообразовательной деятельностью студентов, разноуровневые задания, высшая математика.

Kvitka T. V. Cotrolling self-education activities of students majoring in engineering in learning higher mathematics using multi-level tasks.

The approach for controlling self-education activities of students in learning integral calculus with multi-level tasks is suggested. In the author's opinion, this approach allows to involve first year students in self-education activity. The author examines the ways to control self-education activities of students majoring in «Electrical engineering and electrotechnics» and «Electromechanics» using the theme «Indefinite integral» as an example.

Key words: controlling self-education activities of students, multi-level tasks, higher mathematics.

В умовах надзвичайно динамічної конкуренції на ринку праці, яка викликана технологічним вибухом наприкінці минулого століття, сучасний випускник вищого технічного навчального закладу повинен бути конкурентоздатним та придатним до працевлаштування (Employability). Термін Employability $\epsilon$ досить поширеним у європейському словнику i характеризує сукупність знань, умінь, навичок, володіння підходами до вирішення виробничої ситуації, а також здатність і бажання до неперервного 
удосконалення та професійного розвитку. Придатність до працевлаштування охоплює такі компетентності: рівень самоорганізації, здатність до роботи в групі, уміння виконувати конкретні завдання, навички комунікації та грамотність, знання інформаційних технологій тощо [6, с. 17]. Отже, випускники ВТНЗ повинні володіти навичками самоосвітньої діяльності і бути готовими до постійної зміни середовища праці, що вимагає від працівника постійного оновлення знань, умінь та навичок.

На наш погляд, найбільш прийнятною є модель професійного розвитку фахівця, що пропонується групою психологів на чолі з професором Л. Мітіною, згідно з якою фахівець у своєму професійному розвитку стоїть на шляху творення, нарощування свого професійного потенціалу. Це стає можливим завдяки спеціально побудованому процесу навчання у виші, згідно з яким завдяки співпраці викладача і студента, у останнього підвищується рівень самосвідомості, розвиваються інтегральні характеристики особистості, що призводить до перетворення мотиваційної, інтелектуальної, афективної, поведінкової структур, що зумовлює перехід зовнішньої детермінації у внутрішню [3].

На думку М. Солдатенко, нині проблема управління самоосвітнім процесом розглядається насамперед з погляду можливості переводу «зовнішнього» (з боку вчителя, викладача) управління самоосвітою учнів і студентів в самоуправління цим процесом [8].

На думку П. Підкасистого, головний напрямок діяльності викладача, спрямований на вдосконалення процесу управління навчально-пізнавальною діяльністю студентів у системі навчання, полягає в поступовому перетворенні цілісного педагогічного процесу на самоосвітній, перетворенні, яке відбувається на основі підвищення рівня готовності до самоосвіти кожної особистості [5].

Підготовка майбутнього фахівця як цілісної особистості можлива, на нашу думку, за рахунок розвитку вмінь і навичок самоосвітньої діяльності, які слід формувати, розпочинаючи з перших днів перебування студента у ВТНЗ.

Метою статті є висвітлення використання різнорівневих завдань у процесі вивчення віщої математики у ДВНЗ «Криворізький національний університет» як способу управління самоосвітньою діяльністю студентів інженерних спеціальностей на початку навчання у BTH3.

Цикл природничо-математичних дисциплін студентами напрямів підготовки 6.050701 «Електротехніка та електротехнології» та 6.050702 «Електромеханіка» вивчається на першому та другому курсах, саме в цей час закладаються основи самоосвітньої діяльності студентів на базі виконання самостійної роботи. Саме в цей час формування вмінь, навичок, потреб у самоосвітній діяльності вимагає управління, оскільки випускник школи не володіє повною мірою складниками самоосвітньої діяльності і самоосвіта на початку вишівського навчання має здебільшого ситуативний, стихійний, несистематичний характер.

Управління самоосвітньою діяльністю з використанням різнорівневих завдань будемо розглядати на прикладі викладання вищої математики, зокрема теми «Невизначений інтеграл». У результаті управління самоосвітньою діяльністю у студентів повинна бути сформована система знань, умінь і навичок, що забезпечуватиме оволодіння навчальним матеріалом з вищої математики в умовах переваги самостійної роботи над аудиторною i також сприятиме інтенсифікації навчання студентів і їх розвитку в майбутній професійній діяльності.

У більшості сучасних праць виокремлюють такі функції управління: цілепокладання, планування, організація, контроль, корекція. Процес управління є неперервним і циклічним (Рис. 1). 


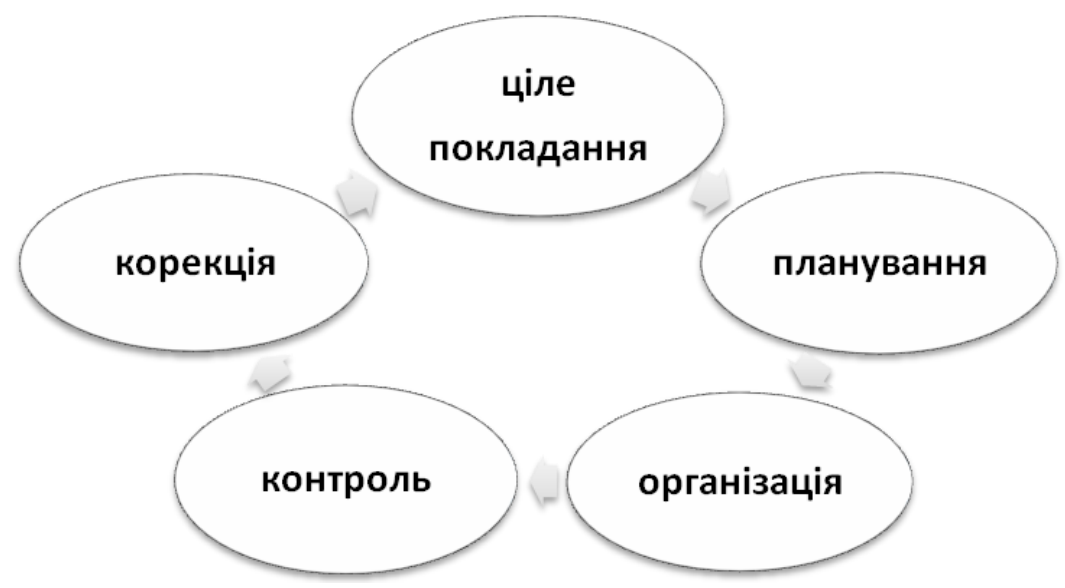

Рис. 1. Функиії управління.

Процес управління освітніми системами має певні особливості і функції управління в них такі: мотиваційно-цільова, інформаційно-аналітична, планово-прогностична, організаційно-виконавча, контрольно-діагностична, регулятивно-корекційна (Рис.2).

Розглядатимемо функції управління самоосвітньою діяльністю студентів за допомогою різнорівневих завдань на прикладі вивчення теми «Невизначений інтеграл», вибір теми зумовлений її широкими зв’язками як у середині дисципліни «Вища математика», так і міждисциплінарними зв'язками зі спеціальними дисциплінами, такими, як ТОЕ, ФОЕ тощо.

Ця тема $є$ складною $\mathrm{i}$ такою, що потребує наполегливої праці студента над оволодінням методами інтегрування. Тому мотиваційно-цільовий компонент на початку вивчення теми, безумовно, буде зовнішній (не відставання від інших учасників групи, намагання отримати позитивну оцінку викладача), при цьому у функції викладача входить демонстрація зв'язків з попереднім матеріалом дисципліни і демонстрація важливості певної теми в майбутньому, завдяки їі внутрішньодисциплінарним та міждисциплінарним зв'язкам. Процес цілепокладання й цілеутворення на початку не самостійний, цілі навчання формуються спільно з викладачем, а лише згодом самостійно.

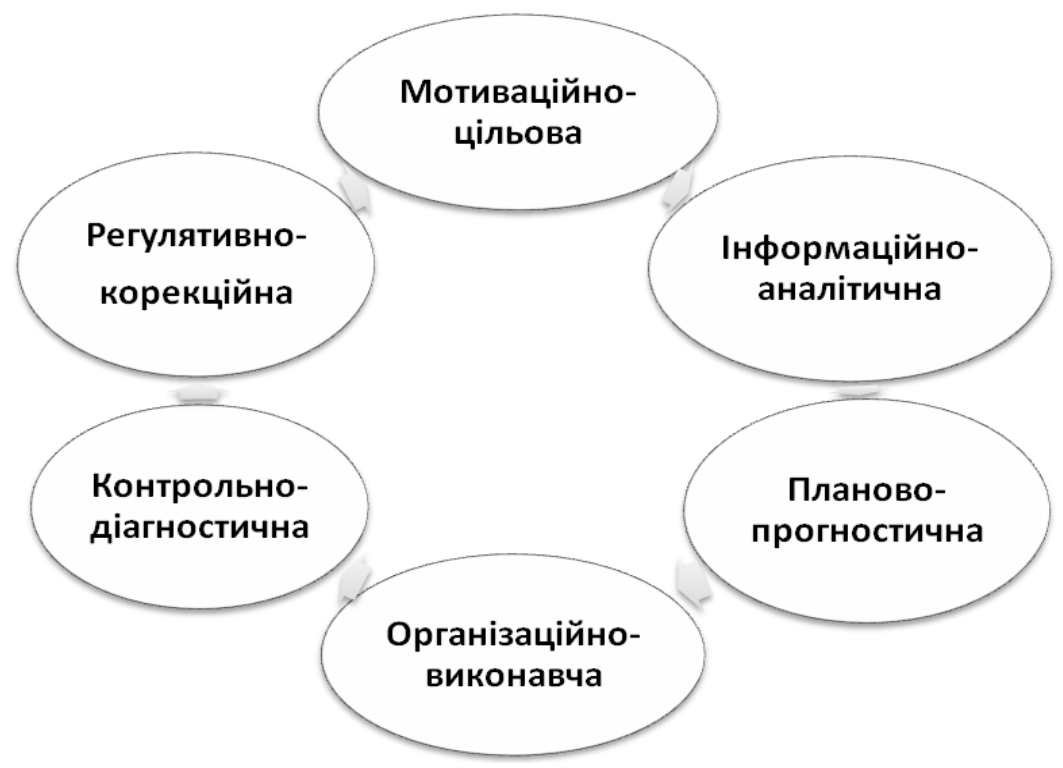

Рис. 2. Функиії управління в освітніх системах 
Інформаційно-аналітична функція управління полягає у якісному підборі лекційного матеріалу, з обов'язковим включенням певної кількості прикладів на застосування методів інтегрування, i активного залучення студентів до їх опрацювання як за допомогою конспектів, так і навчальної, довідкової та методичної літератури. Також корисним на окресленому етапі $є$ складання карт понять, які допомагають студентам систематизувати, виявляти зв'язки та запам'ятовувати навчальний матеріал.

Планово-прогностична функція забезпечується навчальною програмою дисципліни «Вища математика» та навчальною робочою програмою дисципліни «Вища математика» для згадуваних напрямів підготовки, що регламентується структурою залікових та змістових модулів дисципліни [4; 7]

Організаційно-виконавча функція забезпечується за рахунок підбору задач для самостійного й індивідуального виконання за рівнями складності. Завдання для практичних занять та самостійної роботи дібрані за трьома рівнями складності: перший - найпростіший, другий - середній, третій - складний. Виконання завдань певного рівня потребує різного ступеня володіння знаннями, вміннями та навичками. Для першого рівня достатньо знань основних положень і володіння основними прийомами інтегрування, для другого - до вимог першого рівня додаються виконання більш складних обчислень, для третього - завдання включають застосування кількох методів одночасно і можливість застосування різних способів розв'язування, володіння якими оцінюється додатково. Така організація дає можливість мотивувати на навчання як слабких студентів, так і студентів, що мають високий рівень домагань. Виконання в такий спосіб дібраних завдань спонукає студентів до самостійного опрацювання математичної літератури, аналізу та синтезу отриманої інформації з різних джерел, у яких вони можуть бути представленні дещо по-різному, вибір найбільш раціонального шляху розв'язування задачі. Студент має змогу вибору рівня складності і переходу від одного рівня до іншого за власним бажанням та за рекомендацією викладача. Для реалізації такого підходу на кафедрі вищої математики ДВНЗ «Криворізький національний університет» розроблені методичні вказівки до практичних занять 3 теми «Невизначений інтеграл» 3 різнорівневими завданнями [1], які використовуються в навчальному процесі.

Для реалізації контрольно-діагностичної функції розроблені завдання для типових розрахунків, які виконуються студентами індивідуально, відповідно до їх рівня, також типові розрахунки захищаються студентами індивідуально, що надає можливість як контролювати результати самостійної роботи та самоосвітньої діяльності, так і зорієнтувати студента на питання, які необхідно додатково опрацювати. На цьому етапі також виконується контрольна робота з розглядуваної теми.

Регулятивно-корекційна функція реалізується під час консультацій зі студентами, які проводяться після вивчення теми та під час вивчення наступних тем, зміст яких передбачає застосування набутих знань.

Під час такого управління самоосвітньою діяльністю студентів створюється освітнє середовище, яке характеризується залученням студента до навчання, розвиває в них досвід самоосвітньої, креативної діяльності.

Досвід використання різнорівневих завдань під час навчання студентівелектротехніків показує, що при реалізації такого підходу студенти показавши певний результат відчувають самореалізацію, навіть на першому рівні складності, і це надає їм змогу рухатися в напрямку набуття знань, нерідко відбувається перехід між рівнями в бік ускладнення, що забезпечує підвищення якості навчання.

Педагогіка вищої та середної школи. - 2015. - Вип. 45 
Мобільність студентів у виборі рівня сприяє мотивації студентів 3 високим рівнем домагань до самоактуалізації та самонавчання; студенти вчаться самоконтролю, самооцінці й самоуправлінню завдяки можливості самостійно обирати рівень завдань, зіткнувшись 3 труднощами або, навпаки, недостатньою складністю завдань; і мають змогу самостійно організовувати пошук потрібної навчальної інформації.

Використовуючи різнорівневі завдання для організації самостійної роботи студентів, спонукаємо їх до систематичної самоосвітньої діяльності й активізації процесів САМО (самоактуалізації, самонавчання, самоконтролю, самооцінки, самоуправління і самоорганізації), що є запорукою у формуванні конкурентоздатного фахівця, який відповідає вимогам сучасного роботодавця. Подальші дослідження вбачаємо у вдосконаленні реалізації функцій управління самоосвітньою діяльністю студентів інженерних спеціальностей.

\section{Література}

1. Квітка Т. В. Методичні вказівки до вивчення теми «Невизначений інтеграл» 3 дисципліни «Вища математика» для студентів технічних спеціальностей всіх форм навчання 3 різнорівневими завданнями / Т. В. Квітка. - Кривий Ріг : Видавничий центр ДВНЗ «КНУ», 2013. - 28 с. 2. Малихін О. В. Організація самостійної навчальної діяльності студентів вищих педагогічних навчальних закладів: теоретико-методологічний аспект: [монографія] / О. В. Малихін. - Кривий Ріг : Видавничий дім, 2009. - 307 с. 3. Митина Л. М. Психология здоровья человека в глобализирующемся мире: системный личностно-развивающий подход [Электронный $\quad$ pecypc] / $\quad$ Л. М. Митина. - Режим доступа: http://www.enu.kz /repository2014/psihologia-zdorvya.pdf 4. Навчальна програма 3 дисципліни «Вища математика» для студентів напряму підготовки 6.050701 «Електротехніка та електротехнології». - Кривий Ріг : ДВНЗ «Криворізький національний університет», 2012. 20 с. 5. Пидкасистый П. И. Организация учебно-познавательной деятельности студентов / П. И. Пидкасистый. - Москва : Педагогическое общество России, 2005. - 144 с. 6. Рашкевич Ю. М. Болонський процес та нова парадигма вищої освіти: [монографія] / Ю. М. Рашкевич. - Львів : Видавництво Львівської політехніки, 2014. - 168 с. 7. Робоча навчальна програма 3 дисципліни «Вища математика» для студентів напряму підготовки 6.050701 «Електротехніка та електротехнології».- Кривий Ріг: ДВНЗ «Криворізький національний університет», 2013. - 70 c. 8. Солдатенко М. М. Проблеми управління навчально-пізнавальною діяльністю учнів і студентів / М. М. Солдатенко. - Режим доступу: http://lib.iitta.gov. ua/ id/eprint/2905

Любов Клюй

\section{СТРУКТУРУВАННЯ ЗМІСТУ НАВЧАЛЬНОГО МАТЕРІАЛУ КУРСУ ЗА ВИБОРОМ У ПРОЦЕСІ ФАХОВОЇ ПІДГОТОВКИ МАЙБУТНІХ СОЦАЛЬНИХ ПЕДАГОГІВ}

Клюй Л. В. Структурування змісту навчального матеріалу курсу за вибором у процесі фахової підготовки майбутніх соціальних педагогів.

У статті порушено питання розроблення дидактичного супроводу в умовах соціальнопедагогічної підготовки майбутніх соціальних педагогів у змісті курсу за вибором. Дидактичний супровід щодо основних напрямків соціально-педагогічної діяльності певною мірою нівелює перевагу теоретичного блоку дисциплін над практичним, пов'язаним із формуванням фахових умінь і навичок, сприяючи виробленню проективних умінь і навичок 